\title{
What Caused the Summer Replacement of Dominant Planktonic Algae in Lake Barato?
}

\author{
Keishi Takano and Shuji Hino
}

\begin{abstract}
Dense water blooms of blue-green algae (Microcystis aenginosa and Apha. nizomenon flos-aquae) had been observed in hypertrophic Lake Barato in the 1980s, but have not reappeared since 1990. Instead of these water blooms, diatoms (Melosira spp. and Cyclotella spp.) have dominated in summer. Orthophosphate $\left(\mathrm{PO}_{4}-\mathrm{P}\right)$ had been detected throughout the year, but since 1990 has apparently become depleted during May and June. In 1991, $\mathrm{PO}_{4}-\mathrm{P}$ concentrations increased in August and/or September, as did the biomass of blue-green algae (Anabaena spiroides or Phormidium spp.). These observations suggested that diatoms adapted to higher phosphorus limitation under conditions of low water temperature and high silicate concentration. Diatoms thus continued their dominance over blue-green algae because the latter could not grow in early summer due to a lack of $\mathrm{PO}_{4}-\mathrm{P}$, most of which was taken up by the diatoms.
\end{abstract}

Key words : Blue-green algae, diatoms, dominant species, water bloom

\section{Introduction}

Mesocosm and in vitro experiments have shown that water temperature, irradiance, bicarbonate concentration, nutrient concentrations and their ratios affect the replacement of dominant planktonic algae. However, the influence of physico - chemical factors on algal replacement have seldom been reported in a natural lake. TAKAMURA et al. (1992) suggested that an increase in the TN: TP ratio of lake water affected algal succession (from Microcystis aeruginosa to Planktothrix agardhii).

Lake Barato is located near the western coast of central Hokkaido, Japan. It is crescent- shaped with a maximum depth of 13 $\mathrm{m}$ and a surface area of $4.37 \mathrm{~km}^{2}$. This lake is hypertrophic due to the inflow of urban sewage from Sapporo City. A dense water bloom of blue-green algae was observed every summer during the 1980s (HINo and TADA, 1985; HiNo, 1991). However, the dominant planktonic algae changed from blue - green algae to diatoms in 1990, and water blooms of Microcystis aeruginosa and/or Aphanizomenon flos-aquae have not been observed since then.

The recent change from blue-green algae to diatoms is an interesting phenomenon from both a biological and ecological viewpoint. The aim of this study is to examine whether or not changes in nutrient conditions and water temperature have caused this shift.

\section{Materials and methods}

The study was carried out at two sampling sites in L. Barato (Fig. 1), whose numbering follows that given in a previous paper (HiNo and Aor, 1983). Sta. 1 is not affected directly by the inflow of urban wastewater, but Sta. 3 is affected by that as well as by a temporary invasion of seawater. Other limnological characteristics of this lake have been described in previous papers (HiNo and TADA, 1985; HiNO, 1988a, b; 1991; 1992).

Water samples ware collected from the surface layer $(0-2 \mathrm{~m})$ with an acrylic core tube water sampler (diameter $4.4 \mathrm{~cm}$, length $2 \mathrm{~m}$ ) once a month from April 1988 to December 1992 


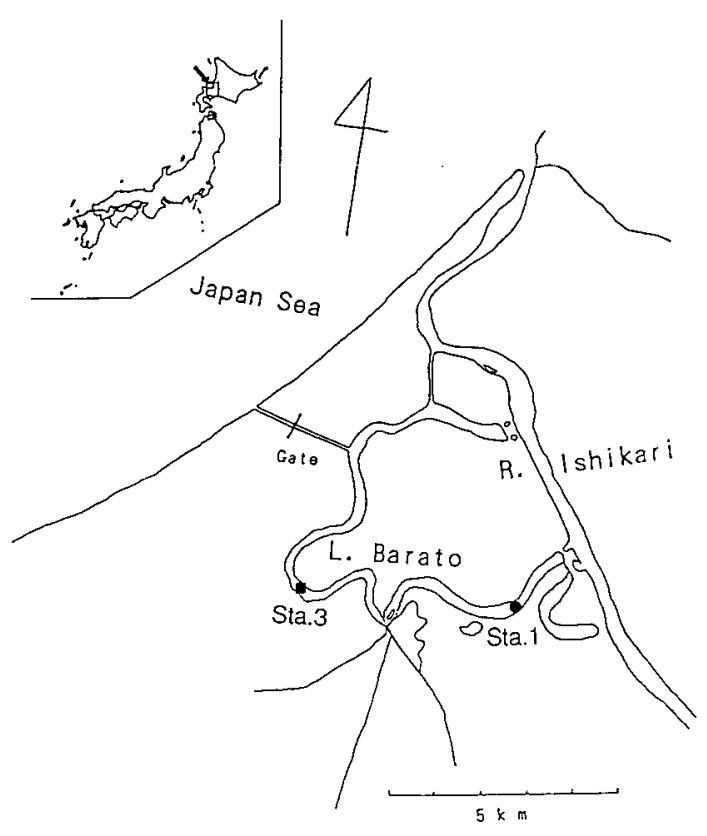

Fig. 1. Map of Lake Barato and the sampling stations.

(O), Sta. 1; (ם), Sta. 3.

except in January and March. Water samples were filtered through Whatman GF/F filters to separate filtrates from residues on the filters.

Water temperature was measured with a thermistor thermometer attached to a YSI dissolved oxygen meter (model 58). Orthophosphate $\left(\mathrm{PO}_{4}-\mathrm{P}\right)$ was measured by the method of MURPHY and RiLey (1962). Measurements of soluble total phosphorus (STP) and total phosphorus (TP) were conducted by the same method as orthophosphate after hydrolysis by the method of Menzel and Corwin (1965). Ammonium nitrogen was measured by the indophenol method (Japan Meteorological Agency, 1970), and nitrate plus nitrite nitrogen by the copper-cadmium reduction method of WOOD et al. (1967). Total inorganic nitrogen (TIN) was expressed as a sum of nitrate, nitrite and ammonium nitrogen. Total nitrogen (TN) was measured by the same method as nitrate nitrogen after hydrolysis with alkaline potassium persulfate (Solorzano and Sharp, 1980). Measurements of silicate $\left(\mathrm{SiO}_{2}\right)$ were by the molybdosilicate method (APHA, 1985), while chlorophy11- $a$ (chl- $a$ ) was measured with a Turner fluorometer model III by the acidification method (SAIJo, 1975) after extraction with methanol.

Water samples for the identification and counting of planktonic algae were fixed with formalin at a final concentration of $5 \%$. Cells were identified and counted under a microscope using a haemacytometer. The average cell volume of each planktonic algal species was obtained by modifying the algal shape into the simplest geometric configuration and measuring more than 30 individuals of each with a micrometer; the total cell volume of each species was then calculated by multiplying the average cell volume by the cell density.

\section{Results}

\section{3-1. Seasonal change in biomass of main phytoplankton species}

Figure 2 shows the seasonal changes in the biomass of the main phytoplankton species at Stas. 1 and 3 from 1990 to 1992 . The dominant species at Sta. 3 in 1988 and 1989 are summarized in Table 1 cited from a previous paper (Hino, 1991). Until 1989, Microcystis aeruginosa and/or Aphanizomenon flos-aquae were dominant and formed a dense water bloom from July to September. No such water bloom has been observed since 1990, and diatoms have since dominated from July to September. Dominant species were Melosira granulata, Cyclotella meneghiniana and Cyclotella sp. (dia. $<15 \mu \mathrm{m}$ ) in 1990, 1991 and 1992, respectively. The total cell volume of diatoms from July to September was particularly high in 1991 and 1992, reaching five times that of blue-green algae after 1991 except in June of that year when Apha. flosaquae occupied $32 \%$ of the total algal volume at Sta. 1. A small amount of Apha. flos-aquae occurred in November 1990 at Sta. 1, and in June and July 1991 and 1992 at both stations. Anabaena spiroides and Phormidium spp. occurred at low densities in September 1991.

The seasonal changes in chlorophyll- $a$ concentration are shown in Figure 3. The maximum concentrations of chlorophyll- $a$ were $100-$ $150 \mu \mathrm{g} \cdot 1^{-1}$ in 1988 and 1989 when the bluegreen algae bloomed. However, since 1990 that 

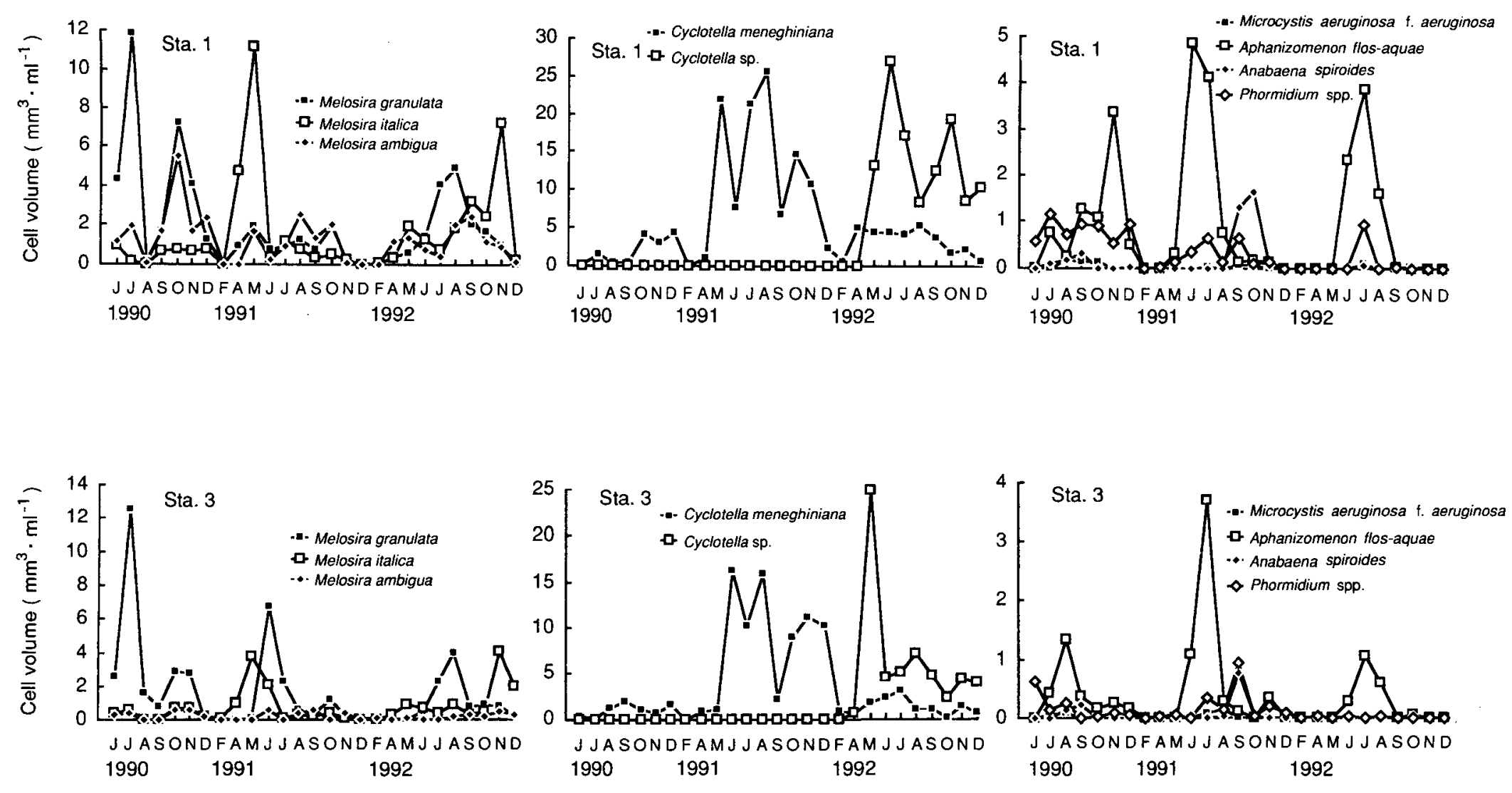

Fig. 2. Seasonal changes in cell volume of the main planktonic algal species in L. Barato from 1990 to 1992. 
Table 1. Seasonal changes in the first and second dominant species at Sta. 3 in L. Barato in 1988 and 1989 (Data from Hino, 1991).

(O), First dominant species; (O), second dominant species.

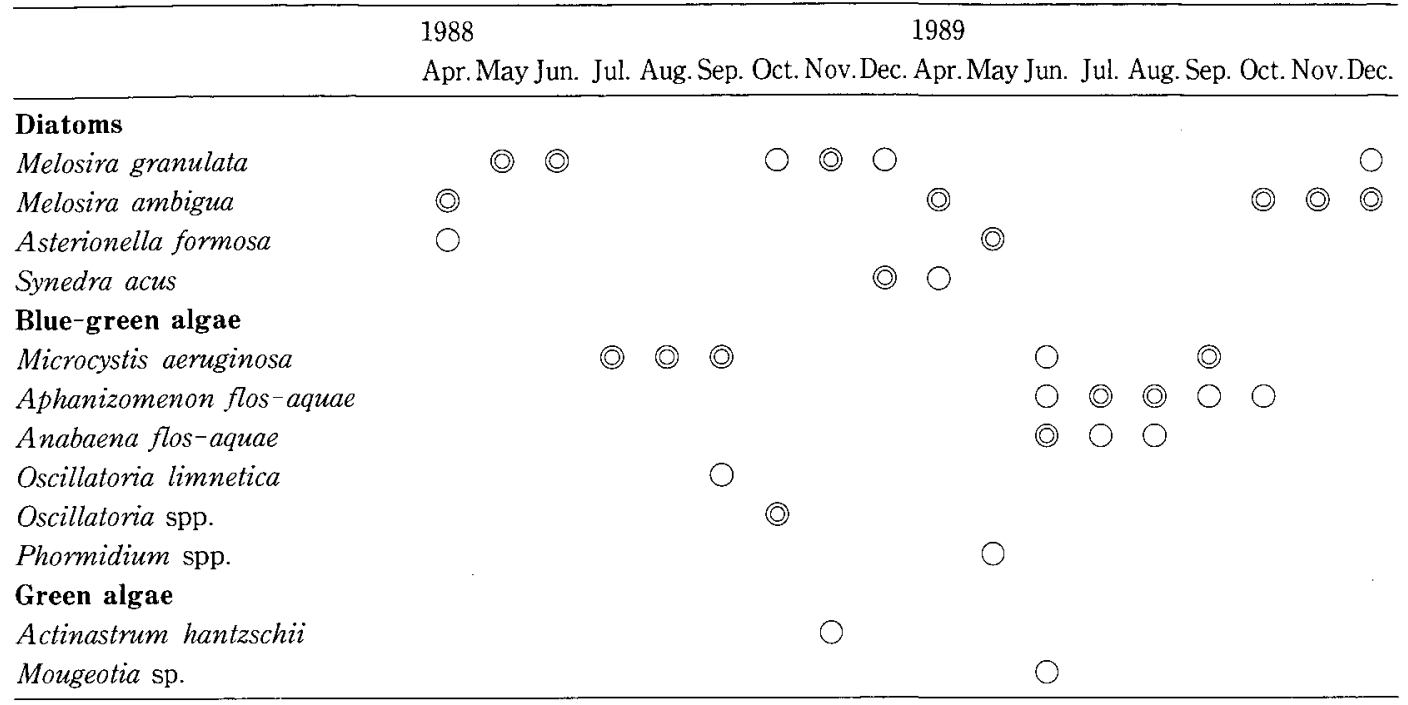

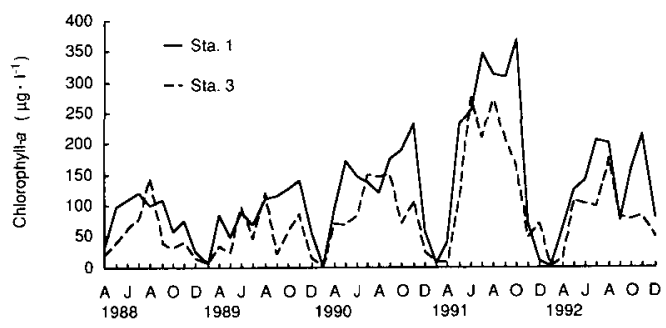

Fig. 3. Seasonal changes in chlorophyll- $a$ concentration in L. Barato from 1988 to 1992 .

concentration has increased with the change of dominant species, with values reaching $369 \mu \mathrm{g} \cdot$ $1^{-1}$ at Sta. 1 in November 1991 and $276 \mu \mathrm{g} \cdot 1^{-1}$ at Sta. 3 in June 1991 due to the vast propagation of diatoms.

\section{3-2. Seasonal changes in water tempera- ture and nutrient concentrations}

Seasonal changes in water temperature are found in Figure 4, and show a slight difference between Stas. 1 and 3 . The maximum annual temperatures range was $23.6-24.9^{\circ} \mathrm{C}$ in 1988 1989. The maximum temperature in 1990 $\left(24.8^{\circ} \mathrm{C}\right)$ was similar to that in previous years, even though the dominant species had changed. Thereafter the temperature decreased during summer, with the maximum falling to 22.1 and

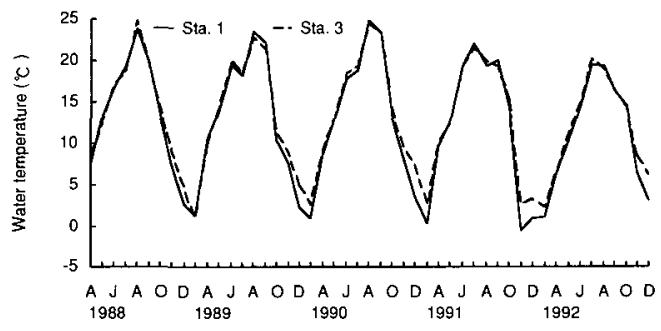

Fig. 4. Seasonal changes in water temperature in L. Barato from 1988 to 1992.

$20.2^{\circ} \mathrm{C}$ in 1991 and 1992 , respectively.

TIN was detected mostly as nitrate-N throughout all seasons at both stations (Fig. 5). After 1990, the concentration level of TIN from July to September was similar to that before 1989. In 1988 and 1989, the range of TN concentration from July to September was $2.8-4.1 \mathrm{mg}$ • $1^{-1}$ and $6.1-9.7 \mathrm{mg} \cdot 1^{-1}$ at Stas. 1 and 3, respectively. Although the range showed no increase in early 1990, it began to increase from late 1990 , reaching 7.9 and $10.2 \mathrm{mg} \cdot 1^{-1}$ at Stas. 1 and 3 , respectively, by 1992 .

The $\mathrm{PO}_{4}-\mathrm{P}$ concentrations in July and August were $0.003-0.009 \mathrm{mg} \cdot 1^{-1}$ at both stations in 1988 and 1989. However, they fell quite low after 1990 (<0.003-0.007 and <0.003-0.005 $\mathrm{mg}$ • 

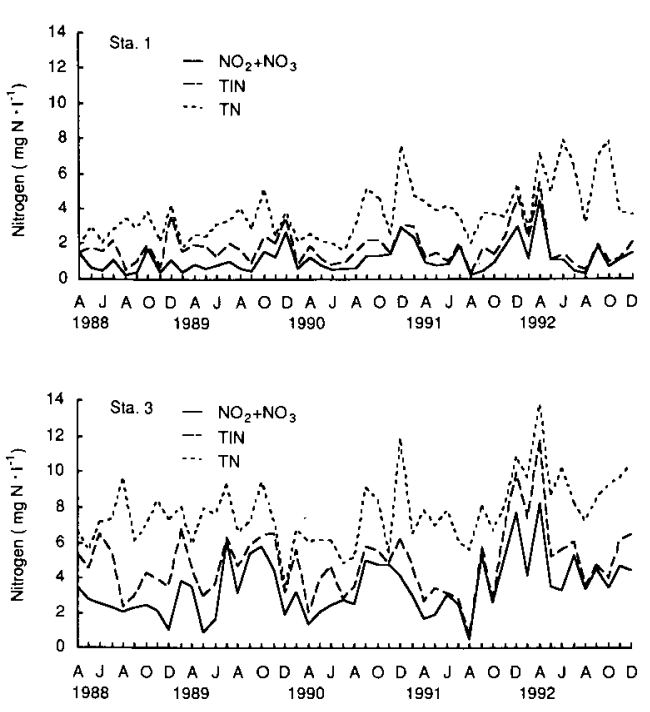

Fig. 5 Seasonal changes in nitrogen concentrations in L. Barato from 1988 to 1992.

$1^{-1}$ at Sta. 1 and Sta. 3, respectively). In particular, $\mathrm{PO}_{4}-\mathrm{P}$ was not detected in the early summer (May and June) after 1990 (Fig. 6). The STP and TP concentrations were relatively stable from year to year (Fig. 7), except for remarkably high TP concentrations from August to October 1991 at Sta. 1.

The $\mathrm{SiO}_{2}$ concentration peaked (17.5-21.2 $\mathrm{mg} \cdot 1^{-1}$ at Sta. 1 and $24.0-26.8 \mathrm{mg} \cdot 1^{-1}$ at Sta. 3 , Fig. 8) when the algal biomass reached its annual minimum each February. The concentration decreased from April to July or August with the increase in diatom biomass. Before 1989, the minimum annual concentration was $1.7-2.4 \mathrm{mg} \cdot 1^{-1}$ and $11.9-14.5 \mathrm{mg} \cdot 1^{-1}$ at Stas. 1 and 3, respectively. After 1990, it maintained its old level at Sta. 1, but fell to below $10 \mathrm{mg}$ $1^{-1}$ at Sta. 3.

\section{Discussion}

The summer water temperature as a whole was lower after 1991 than before 1990 (Fig. 4), with the difference in the maximum being about $4^{\circ} \mathrm{C}$. Tilman et al. (1986) observed that bluegreen algae dominated in low $\mathrm{N}: \mathrm{P}$ ratios $\left(\mathrm{NO}_{3}-\mathrm{N}: \mathrm{PO}_{4}-\mathrm{P}\right.$ ratios in a synthetic medium) at $24^{\circ} \mathrm{C}$, but not in low $\mathrm{N}: \mathrm{P}$ ratios at 10 and $17^{\circ} \mathrm{C}$ in laboratory experiments using a natural

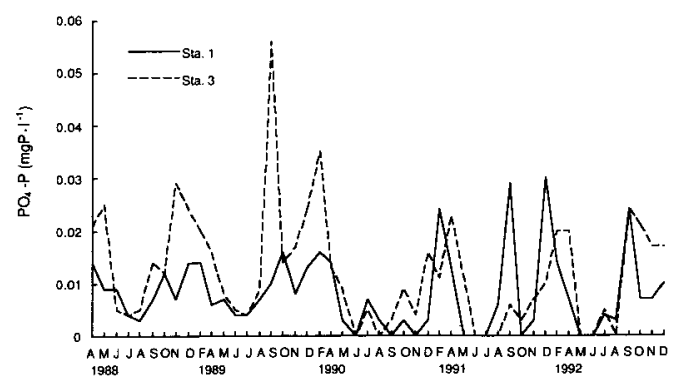

Fig. 6. Seasonal changes in orthophosphate concentration in L. Barato from 1988 to 1992 .
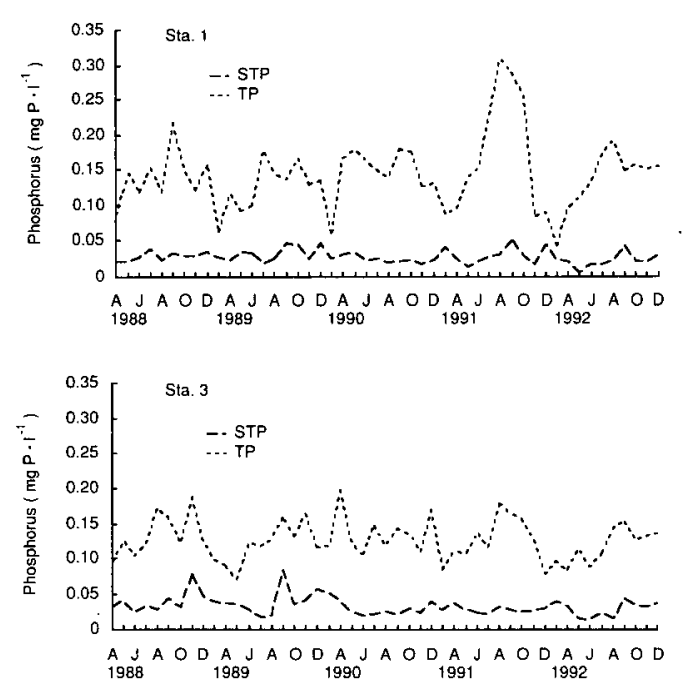

Fig. 7. Seasonal changes in total and soluble total phosphorus concentrations in $\mathrm{L}$. Barato from 1988 to 1992.

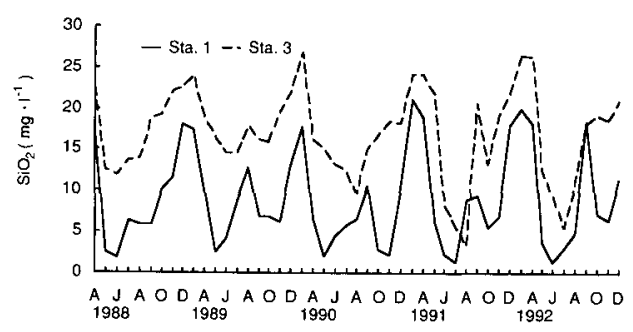

Fig. 8. Seasonal changes in silicate $\left(\mathrm{SiO}_{2}\right)$ concentration in L. Barato from 1988 to 1992 .

algal assemblage. In contrast, diatoms dominated at $9-17^{\circ} \mathrm{C}$ under a broad range of $\mathrm{N}$ : $\mathrm{P}$ ratios unless they were silicate-limited. The lowering of water temperature during the 
period when blue- green algae grow may have induced the dominance of diatoms after 1991.

However, diatom dominance in the summer of 1990 cannot be explained by low water temperature alone. Nutrient conditions are also important for the dominance of planktonic algae. Microcystis aeruginosa requires a fairly high concentration of phosphorus for its growth (Holm and Armstrong, 1981), and is usually abundant where the phosphorus supply is at a high level. We hypothesize that a sufficient $\mathrm{PO}_{4}-\mathrm{P}$ supply is necessary to form a dense blue-green algal bloom, since much TIN remains in L. Barato in all seasons. Although marked variations in TP and STP concentrations in summer were not observed before 1989 and after 1990 , the $\mathrm{PO}_{4}-\mathrm{P}$ concentration has been clearly depleted in May and June at Stas. 1 and 3 since 1990 (Figs. 6 and 7). This depletion might be due to a remarkable increase in uptake by diatoms. Therefore, after 1990, $M$. aeruginosa could not begin to grow due to a lack of phosphorus in early summer. STP (containing dissolved organic phosphorus) is also defined as a source of $\mathrm{PO}_{4}-\mathrm{P}$ supply for planktonic algae. However, Hino (1988c) reported that planktonic algae including $M$. aeruginosa and Melosira spp. could not directly utilize most of the dissolved organic phosphorus in L. Barato.

The biomass of Anabaena spiroides (Stas. 1 and 3) and Phormidium spp. (Sta. 3) increased in September 1991 (Fig. 2) along with an increase in $\mathrm{PO}_{4}-\mathrm{P}$ concentration (Fig. 6). This observation supports the hypothesis that the $\mathrm{PO}_{4}-\mathrm{P}$ supply was sufficient to form a blue-green algal bloom at that time. From 1991, Apha. flos-aquae appeared in June and July when $\mathrm{PO}_{4}-\mathrm{P}$ was undetected. This species was found in lower temperatures, and therefore found in an earlier season than M. aeruginosa (HiNo and TADA, 1985). Since Apha. flos-aquae perhaps began to grow in May before a drop in the concentration of $\mathrm{PO}_{4}-\mathrm{P}$, it may have taken up sufficient $\mathrm{PO}_{4}-\mathrm{P}$ to put in a slight, temporary appearance in June and July.

Since changes in concentrations of chlorophyll- $a$ and TP occurred simultaneously
(Figs. 3 and 7), algal biomass should correspond to TP concentration. While the chlorophyll- $a$ concentrations in the summer increased after 1990, TP concentrations in the summer scarcely changed before 1989 and after 1990. The phosphorus content and phosphorus demand of diatoms, which were dominant after 1990, may be less than those of blue-green algae. Holm and Armstrong (1981) suggested that Asterionella formosa was superior to $M$. aer. uginosa under phosphorus limitation, which they based on a comparison between the nutrient parameters of the two species. In a field survey, JEwson et al. (1981) observed that the biomass of Melosira italica and Stephanodiscus astraea increased in Lough Neagh when soluble reactive phosphorus was below the detection limit. These facts suggest that diatoms are more adaptive to phosphorus deficient conditions than blue- green algae. Hewever, Nedoma et al. (1993) reported that the blue- green algae, Apha. flos- aquae and M. aeruginosa, dominated during a period of phosphorus limitation.

Tilman (1982) proposed that dominant phytoplankton species were determined by the limiting resource ratios. Subsequently, it has been generally accepted that the $\mathrm{N}: \mathrm{P}$ ratio is an important determinant of the species composition of natural algal populations in lakes. TAKAmura et al. (1992) reported a change in dominant algae from $M$. aenuginosa to Planktothrix (Oscillatoria) agardhii in Lake Kasumigaura, and suggested that such a shift was caused by an increase in the TN : TP ratio of the lake water due to an increase in TN.

By plotting the data on TN : TP ratios of 17 lakes from various geographical regions, SMITH (1983) suggested that blue-green algae dominated where the TN : TP ratio was less than 29 (by weight). However, he noted that there were many lakes dominated by non-bluegreen algae despite TN : TP ratios less than 29. From July to September prior to 1989 , the average TN : TP ratios at Stas. 1 and 3 in $\mathrm{L}$. Barato were 21.3 and 55.3 (by weight), respectively. Thereafter, a slight increase in the TN : TP ratio was observed (Figs. 5 and 7). Since the change in dominant algae was noted at both 
stations despite the considerable difference in the TN : TP ratios between them, the shift in dominant algal species cannot be explained by the change in $\mathrm{TN}$ : TP ratio.

The high concentration of $\mathrm{SiO}_{2}$ in $\mathrm{L}$. Barato may contribute to the dominance of diatoms. Although much $\mathrm{SiO}_{2}$ was taken up by diatom growth, it remained relatively abundant from 1988 to 1992 (minimum concentration, $1.2 \mathrm{mg}$ $1^{-1}$, Fig. 8). JEwson et al. (1981) concluded that a decrease in diatom biomass is caused by a deficiency in $\mathrm{SiO}_{2}$ rather than in $\mathrm{PO}_{4}-\mathrm{P}$. The amount of $\mathrm{SiO}_{2}$ taken up by diatoms in $\mathrm{L}$. Barato was estimated to be $10-15 \mathrm{mg} \cdot 1^{-1}$, based either on the difference between maximum and minimum $\mathrm{SiO}_{2}$ concentrations (Fig. 8) or on the calculation of silicate content in the maximum diatom biomass according to the method of Bailey-Watts et al. (1989). If the maximum $\mathrm{SiO}_{2}$ concentration was below 10 $\mathrm{mg} \cdot 1^{-1}$, the diatom biomass should not have increased in the early summer since sufficient $\mathrm{SiO}_{2}$ was lacking. The minimum $\mathrm{SiO}_{2}$ concentration in other lakes whose maximum $\mathrm{SiO}_{2}$ concentration was below $10 \mathrm{mg} \cdot 1^{-1}$ was less than $0.5 \mathrm{mg} \cdot 1^{-1}$ resulting in a decrease in the biomass of planktonic diatoms apparently due to $\mathrm{SiO}_{2}$ limitation (Conway et al., 1977; GibSON, 1981 ; BAILEY-WATTs et al., 1989). In contrast, diatoms in L. Barato maintained an abundant biomass in summer without being limited by $\mathrm{SiO}_{2}$.

It seems likely that $\mathrm{PO}_{4}-\mathrm{P}$ depletion by the uptake of diatoms in early summer was the main factor influencing a change in the dominant species in L. Barato, and that low water temperature and high $\mathrm{SiO}_{2}$ concentration helped to promote this change.

\section{Acknowledgments}

Special thanks are due to officers of Ishikari town for their help in collecting samples. We also wish to thank Dr. M. Mizuno of Tokyo University of Agriculture (Abashiri) for the identification of diatom species, and Prof. Y. TEZUKA of Kyoto University for corrections to this manuscript and other valuable comments.

\section{摘要 \\ 何が茨戸湖の夏季優占浮遊藻類種を 変化させたか?}

茨戸湖において, 1989 年以前の夏季の優占種で あり,例年濃密な水の華を形成していた Microcys tis aeruginosa などのラン藻が 1990 年以後には活 とんど出現せず，替わって同時期にケイ藻種が優 占するようになった。リン酸態リン $\left(\mathrm{PO}_{4}-\mathrm{P}\right)$ 濃 度は 1989 年以前では年間を通じて常に検出され ていたが，1990 年以後，5，6月には検出されなく なり，リンが次之していると考えられた。1991 年 には、8 9 月に $\mathrm{PO}_{4}-\mathrm{P}$ 濃度が再び增加した直後 に数種のラン藻の発生が認められた。これらのこ とから, ラン藻からケイ藻への優占種の移行は, 夏季に優占していた M. aenuginosa の成長が始ま るであろう5,6月にケイ藻による取り込みによっ て $\mathrm{PO}_{4}-\mathrm{P}$ が欠之したため, その現存量を増加さ せることができず，替わってりン制限状態に強い ケイ藻種が, 低水温下, 高いケイ酸濃度の状況下 で入れ替わって好適に細胞数を増加させ, 夏季ま で優占したために起きたものと推定した。

\section{References}

APHA (1985): Standard methods for the examina. tion of water and wastewater. 16th ed. APHA. AWWA. WPCF.

Bailey-Watts, A. E., I. R. Smith and A. Kirika (1989): The dynamics of silica in a shallow diatom- rich Scottish loch II : The influence of diatoms on an annual budget. Diatom Res., 191- 205.

Conway, H. L., J. I. Parker, E. M. Yaguchi, and D. L. MelLinger (1977): Biological utilization and regeneration of silicon in Lake Michigan. J. Fish. Res. Board Can., 34 : 537-544.

Grbson, C. E. (1981) : Silica budgets and the ecology of planktonic diatoms in an unstratified lake (Lough Neagh, N. Ireland). Int. Revue ges. Hydrobiol., 66 : 641- 664 .

Hino, S. (1988a): Variations in physiological states corresponding to cellular phosphorus contents in freshwater phytoplankton- correlations with adenylate energy charge and photosynthetic activity. Arch. Hydrobiol., 113: 295- 305.

HıNo, S. (1988b) : Extracellular release of organic matter associated with the physiological state of freshwater blue-green algae. Arch. Hydrobiol., 113 : 307-317. 
Hino, S. (1988c): Fructuation of algal alkaline phosphatase activity and the possible mechanisms of hydrolysis of dissolved organic phosphorus in Lake Barato. Hydrobiologia, 157 : 77- 84 .

HINo, S. (1991): Characterization of several types of lake in Hokkaido, Japan: Situations of eutrophication and phytoplankton biomass in Lake Barato, Lake Akan, Lake Shikaribetu. p. 123- 140. In M. Aizaki and H. Tachibana (eds.) Limnological comparison of characteristics of water quality in Chinese and Japanese lakes. Proc. Symp. Hokkaido Univ. "Limnological Comparison of Chinese and Japanese Lakes".

Hino, S. (1992): The physiological state of the phytoplankton community of three types of lakes as estimated by its adenylate energy charge. Hydrobiologia, 230: 179- 192.

Hino, S. and T. Aor (1983): The changes in water qualities of Barato River from 1978 to 1982. Rep. Hokkaido Res. Inst. Environ. Pollut., 10 : 142- 146.

Hino, S. and S. TADA (1985): Seasonal changes of nutrients, Chlorophyll- $a$, and organic matter concentrations in highly eutrophic Lake Barato, Japan. Jpn. J. Limnol., $46: 268-278$.

Holm, N. P. and D. E. ARMSTrong (1981): Role of nutrient limitation and competition in controlling the populations of Asterionella formosa and Microcystis aeruginosa in semicontinuous culture. Limnol. Oceanogr., $26: 622-634$.

Japan Meteorological Agency (1970): Manuals for Oceanographical Observation. Japan Weather Association.

Jewson D. H., B. H. Riprey and W. K. Gilmore (1981): Loss rates from sedimentation, parasitism, and grazing during the growth, nutrient limitation, and dormancy of a diatom crop. Limnol. Oceanogr., 26 : 1045- 1056.

Menzel, D. W. and N. Corwin (1965): The measurement of total phosphorus in seawater based of the liberation of organically bound fractions by persulfate oxidation. Limnol. Oceanogr., 10 : 280-282.

MurPhy, J. and J. P. Rlley (1962) : A modified single solution method for the determination of phos- phate in natural waters. Anal. Chim. Acta, 27 : 21-36.

Nedoma, J., P. Porcalova, J. Komarkova and V. Vyhnalek (1993) : A seasonal study of phosphorus deficiency in a eutrophic reservoir. Freshwat. Biol., 30: 369-376.

SAJJo, Y. (1975): Series of limnological experiment I (Method in chlorophyll measurement). Jpn. J. Limnol., 36: 103-109.

Sмгтн, V. H. (1983) : Low nitrogen to phosphorus ratios favor dominance by blue-green algae in lake plankton. Science, 221: 669-671.

Solorzano, L. and J. H. Sharp (1980): Determination of total nitrogen in natural waters. Limnol. Oceanogr., $25:$ 751-754.

Takamura, N., A. Otsuki, M. Aizaki and Y. Nojiri (1992) : Phytoplankton species shift accompanied by transition from nitrogen dependence to phosphorus dependence of primary production in Lake Kasumigaura, Japan. Arch. Hydrobiol., 124 : 129-148.

Tilman, D. (1982): Resource competition and com. munity structure. Princeton University.

Tilman, D., R. Kiesling, R. Sterner, S. S. Kilham and F. A. Johnson (1986): Green, bluegreen and diatom algae: Taxonomic differences in competitive ability for phosphorus, silicon and nitrogen. Arch. Hydrobiol., 106 : 473-485.

Wood, E., F. A. Armstrong and F. A. Richards (1967):

Determination of nitrate in seawater by cadmium-copper production to nitrite. J. Mar. Biol. Ass. U. K., 47 : 22-31.

(著者：高野敬志，北海道立衛生研究所生活科学部， 厂 060 札幌市北区北 19 条西 12 丁目; 日野修次, 北海 道環境科学研究センター環境科学部, $\overline{0} 060$ 札幌市北 区北 19 条西 12 丁目 ; Keishi TAKano, Environmental Hygiene Department, Hokkaido Institute of Public Health, Kita-19 Nishi-12,Kita-ku, Sapporo, 060 ; Shuji Hino, Environmental Studies Department, Hokkaido Institute of Environmental Sciences, Kita-19 Nishi-12, kita-ku, Sapporo, 060)

Received : 15 June 1994

Accepted : 4 October 1994 